\title{
HUBUNGAN JALUR MIGRASI PENYU LEKANG (Lepidochelys olivacea) TERHADAP TINGGI MUKA LAUT, SUHU PERMUKAAN LAUT, KLOROFIL-a di PERAIRAN INDONESIA Monica Evi Suanty Manurung, Agus Hartoko, Subiyanto*)
}

\author{
Jurusan Perikanan, Fakultas Perikanan dan Ilmu Kelautan, Universitas Diponegoro \\ Jl. Prof. H. Soedharto, SH, Tembalang Semarang. 50275 Telp/Fax (024) 7474698
}

\begin{abstract}
Abstrak
Penyu adalah satwa yang terancam kepunahannya. Transmitter dalam pemantauan penyu dapat memberikan data jelajah penyu yang akurat beserta parameter oseanografinya. Metode penelitian ini menggunakan metode deskripsi. Tahapan penelitian meliputi pengambilan data dari satelit NOAA (tinggi muka laut, suhu permukaan laut dan klorofil-a) dan data titik koordinat penyu. Data kemudian diolah dengan menggunakan Er Mapper 7.0. Hasil dari penelitian ini menunjukkan bahwa penyu lekang yang telah di pasang transmitter terpantau jalur migrasinya dari Selat Bali, Gilimanuk, Bali Utara,/Situbondo, Selat Madura, Madura Utara dan Selat Makassar. Distribusi tinggi muka laut berdasarkan titik koordinat penyu selama lima bulan (Juni, Juli, Agustus, November dan Desember) 2009 pada 7 lokasi yang berbeda yaitu dengan nilai minimum $44 \mathrm{~cm}$ dan maksimum $79 \mathrm{~cm}$, sedangkan distribusi suhu permukan laut dengan nilai minimum $26^{\circ} \mathrm{C}$ dan maksimum $30^{\circ} \mathrm{C}$, dan untuk distribusi klorofil-a dengan nilai minimum 0.219 $\mathrm{mg} / \mathrm{m}^{3}$ dan nilai maksimum $2.77 \mathrm{mg} / \mathrm{m}^{3}$. Korelasi/keeratan hubungan posisi penyu terhadap tinggi muka laut, dengan nilai (r) yaitu 0.873 mempunyai interpretasi atau hubungan yang tinggi. Nilai $(r)$ suhu permukaan laut yaitu 0.78 menunjukkan bahwa interpretasi sedang, dan untuk klorofil-a didapatkan nilai (r) yaitu 0.69, nilai ini menunjukkan bahwa interpretasi sedang.
\end{abstract}

Kata kunci: Jalur migrasi penyu, Transmitter, NOAA (Tinggi muka laut,Suhu permukaan, Klorofil-a).

\begin{abstract}
Sea Turtle is one of species lead to extinction. Transmitters had been set on the coordinate of sea turtle observation provides highly accurate data along with complete oceanographic parameters. The research used descriptive coordinate. Stages in this research includes collection of data from NOAA satellite imagery (sea surface height, sea surface temperature, level of chlorophyll-a) and sea turtle coordinate data. The data is then processed with Er Mapper 7.0. The research shows that transmitter of the tagged olive ridley/sea turtle migrate from the waters of Bali strait, Gilimanuk, Northen Bali, Situbondo, Madura Strait, Northern Madura, and Makassar strait. Distribution of sea surface height based on coordinate location of the sea turtle during five different months (June, July, August, September, and December) 2009 at 7 different locations shows minimum value of $44 \mathrm{~cm}$ and maximum value of $79 \mathrm{~cm}$. Whereas the distribution of sea surface temperature shows a minimum value of $26^{\circ} \mathrm{C}$ and maximum value of $30^{\circ} \mathrm{C}$, and the distribution of chlorophyll-a shows a minimum value of $0.219 \mathrm{mg} / \mathrm{m}^{3}$ and maximum value of 2.77 $\mathrm{mg} / \mathrm{m}^{3}$. The correlation coefficient between the position of sea turtle and sea surface height has shown a high correlation with values of $(r) 0.873$. The $(r)$ value for sea surface temperature of 0.78 was interpreted as medium correlation. The ( $r$ ) values of chlorophyll a was shown at 0.69 was interpreted as medium correlation.
\end{abstract}

Keywords: Sea turtle migratory course, Transmitter, NOAA (Sea surface level, sea surface temperature, level of chlorophyll-a).

\section{Pendahuluan}

Populasi penyu semakin berkurang bahkan terancam punah sehingga penyu dilindungi oleh undang-undang, baik secara nasional maupun internasional. (Dirjen Perikanan, 1993). Tanpa disadari bahwa punahnya salah satu jenis sumberdaya alam seperti penyu akan menyebabkan terjadinya ketidakseimbangan ekosistem dan hilangnya plasma nutfah yang penting bagi dunia ilmu pengetahuan. Metode yang telah digunakan untuk penentuan jalur migrasi penyu saat ini, yaitu dengan menggunakan teknik tradisional yaitu tagging set yang dipasang (kode tag ID) pada induk penyu betina yang sedang mendarat saat bertelur di pantai dan saat di penangkaran maupun penemuan induk penyu oleh nelayan, setelah proses tagging selesai, langkah berikutnya menunggu dan memantau penyu tersebut kembali lagi saat bertelur di daerah yang sama maupun daerah yang berbeda, bila ditemukan penyu yang 
diberi tagging maka diisi berita acara kemudian diarsipkan. Menurut Samedi (2000), kelemahan metode ini tidak dapat mengetahui jalur migrasi penyu dengan akurat dan akan mengabaikan parameter oseanografi yang dihadapi oleh penyu saat pergerakannya di perairan. Penyu merupakan satwa yang sangat migran sehingga suatu daerah tidak dapat menggambarkan jumlah populasi penyu di daerah tersebut. Oleh karena itu, perlu dilakukan penelitian yang mampu memberikan data jelajah penyu yang akurat beserta parameter oseanografinya yaitu melalui pengolahan data satelit NOAA (National Oceanic and Atmospheric Administration) karena penyu memiliki fungsi penting dalam ekosistem dan sebagai spesies indikator (bio-indikator) untuk menentukan kondisi suatu habitat perairan. Berdasarkan hal tersebut, satwa ini dapat digunakan sebagai media untuk melakukan observasi laut, monitoring perubahan lingkungan dan penentuan Kawasan Konservasi Laut (KKL).

Tujuan dari penelitian ini adalah: Mengetahui jalur migrasi penyu lekang (L. olivacea) yang telah dipasang transmitter, dan mengetahui distribusi Tinggi Muka Laut (TML), Suhu Permukan Laut (SPL), Klorofil-a pada titik koordinat penyu lekang (L. olivacea) yang telah dipasang transmitter dengan menggunakan pengolahan satelit NOAA (National Oceanic and Atmospheric Administration) serta mengetahui korelasi hubungan titik koordinat penyu lekang (L. olivacea) terhadap distribusi Tinggi Muka Laut (TML), Suhu Permukan Laut (SPL) dan Klorofil-a. Pengelolaan data penelitian telah dilaksanakan pada bulan November-Desember 2012 di Laboratorium Geospasial Pesisir Parangtritis, Yogjakarta dan Laboratorium Penginderaan Jauh, Jurusan Perikanan, FPIK. Universitas Diponegoro.

\section{Materi dan Metode Penelitian \\ A. Materi Penelitian}

Materi yang digunakan dalam penelitian ini adalah pergerakan migrasi induk penyu lekang (L. olivacea) berjenis kelamin betina yang telah dipasang alat transmitter, diambil dari kelompok pelestari penyu Kurma Asih, Perancak, Bali. Untuk proses penelitian dan pengolahan data satelit menggunakan peralatan yaitu perangkat Notebook Intel Pentium P6200 (2.13 GHz) 2 GB RAM yang merupakan perangkat keras (hardware) yang digunakan sebagai sarana penunjang sistem operasi dan program yang akan dijalankan untuk pengolahan data NOAA. Er Mapper 7.0 untuk melakukan proses gridding (geo statistik), overlay dan layout peta persebaran tinggi muka laut, suhu permukaan laut, dan klorofil-a, Microsoft Excel 2003 dan SPSS 16 untuk analisis korelasi, flashdisk Toshiba 4 GB, kamera digital untuk dokumentasi. Bahan yang digunakan terdiri dari data satelit NOAA serta peta Bathymetry rupa bumi Indonesia (sumber: Marine Geomatic Center, UNDIP/Agus Hartoko) dan data titik koordinat penyu lekang (L. olivacea) bulan Mei - Desember 2009. (sumber: Badan Penelitian Observasi laut (BPOL), Perancak, Bali) serta Data Satelit NOAA Tinggi Muka Laut (TML), Suhu Permukaan Laut (SPL), Klorofil-a.

\section{B. Metode Penelitian, Pengolahan dan Analisis Data}

Metode penelitian ini menggunakan metode deskripsi, yaitu penelitian yang bermaksud untuk menggambarkan objek yang diteliti sesuai dengan apa adanya, sehingga didapatkan deskripsi secara sistematis sesuai dengan fakta dan karakteristik objek yang diteliti secara tepat (Notoatmodjo, 2002). Penelitian ini menganalisis tiga variabel yang diduga memiliki hubungan atau berpengaruh terhadap jalur migrasi penyu lekang yaitu analisis sebaran suhu permukaan laut dari data NOAA. Analisis sebaran tinggi muka laut, suhu permukaan laut, klorofil-a pada data Altimetri (NOAA) di download dari website: Ocean Watch. Analisis sebaran tinggi muka laut, suhu permukaan laut dan klorofil-a diperoleh dari data numerik/ASCII yang selanjutnya akan diproses menggunakan software Er-Mapper 7.0 untuk menghasilkan data spasial masing-masing variabel yaitu peta persebaran tinggi muka laut, peta persebaran suhu permukaan laut dan peta persebaran klorofil-a. Analisis masing-masing variabel oseanografi dilakukan untuk mengetahui pengaruh tinggi muka laut, suhu permukaan laut dan klorofil-a terhadap posisi titik koordinat penyu selama melakukan migrasi, sehingga dapat dihubungkan antara distribusi tinggi muka laut, suhu permukaan laut dan klorofil-a dengan titik koordinat penyu.

\section{Analisis korelasi}

Untuk menilai hubungan antara variabel (tinggi muka laut, suhu permukaan laut dan klorofil-a) dengan titik koordinat penyu digunakan analisis regresi, didapatkan nilai koefisien korelasi ( $r$ ) dan nilai koefisien determinasi $\left(\mathrm{R}^{2}\right)$ kemudian dianalisa hubungannya. Regresi tunggal (single regression) dan regresi Ganda (multiple regression) menggunakan persamaan yaitu:

$$
\begin{aligned}
\mathrm{Y}=\mathrm{ax}^{2}+\mathrm{bx}+\mathrm{c}, & \text { dimana: } \\
\mathrm{Y} & =\text { variabel terikat (tinggi muka laut) } \\
\mathrm{X} & \text { = variabel bebas (titik koordinat penyu bujur dan lintang) } \\
\mathrm{Y}=\mathrm{ax}^{2}+\mathrm{bx}+\mathrm{c}, & \text { dimana: } \\
\mathrm{Y} & =\text { variabel terikat (suhu permukaan laut) } \\
\mathrm{X} & =\text { variabel bebas (titik koordinat penyu bujur dan lintang) } \\
\mathrm{Y}=\mathrm{ax}^{2}+\mathrm{bx}+\mathrm{c}, & \text { dimana: } \\
\mathrm{Y} & =\text { variabel terikat (klorofil-a) } \\
\mathrm{X} & =\text { variabel bebas (titik koordinat penyu bujur dan lintang) }
\end{aligned}
$$

Sedangkan, regresi ganda (multiple regression) menggunakan persamaan: $\mathrm{Y}=\mathrm{a}+\mathrm{bx}_{1}+\mathrm{cx}_{2}+\mathrm{dx}_{3}$, dimana: 
$=$ titik koordinat bujur dan lintang

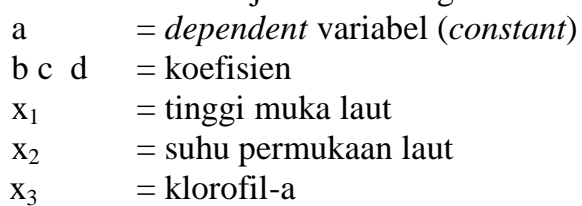

Menurut Hadi (2004), koefisien korelasi selalu bergerak yaitu diantara $-1 \geq \mathrm{r} \leq 1$. Koefisien korelasi antara 0 sampai +1 menunjukkan korelasi yang positif sedangkan dari - 1 sampai 0 menunjukkan korelasi yang negatif.

Tabel 1. Klasifikasi Nilai Koefisien Korelasi

\begin{tabular}{cc}
\hline Koefisien Korelasi (r) & Interpretasi \\
\hline $0,8-1$ & Tinggi \\
$0,6-0,8$ & Cukup tinggi \\
$0,4-0,6$ & Agak rendah \\
$0,2-0,4$ & Rendah \\
$0,0-0,2$ & Sangat rendah (Tak berkorelasi) \\
\hline
\end{tabular}

\section{Hasil dan Pembahasan}

Sumber : Hadi (2004)

\section{Jalur migrasi penyu lekang}

Induk penyu lekang yang dipasang transmitter Kiwisat 101, telah terpantau jalur migrasinya selama 5 (lima) bulan yaitu Juni, Juli, Agustus, November dan Desember tahun 2009. Data-data yang diterima memberikan informasi keberadaan posisi penyu tersebut saat melakukan migrasi dari Selat Bali, Gilimanuk, Bali Utara, Selat Madura, Madura Utara, menuju Laut Jawa hingga Selat Makassar:

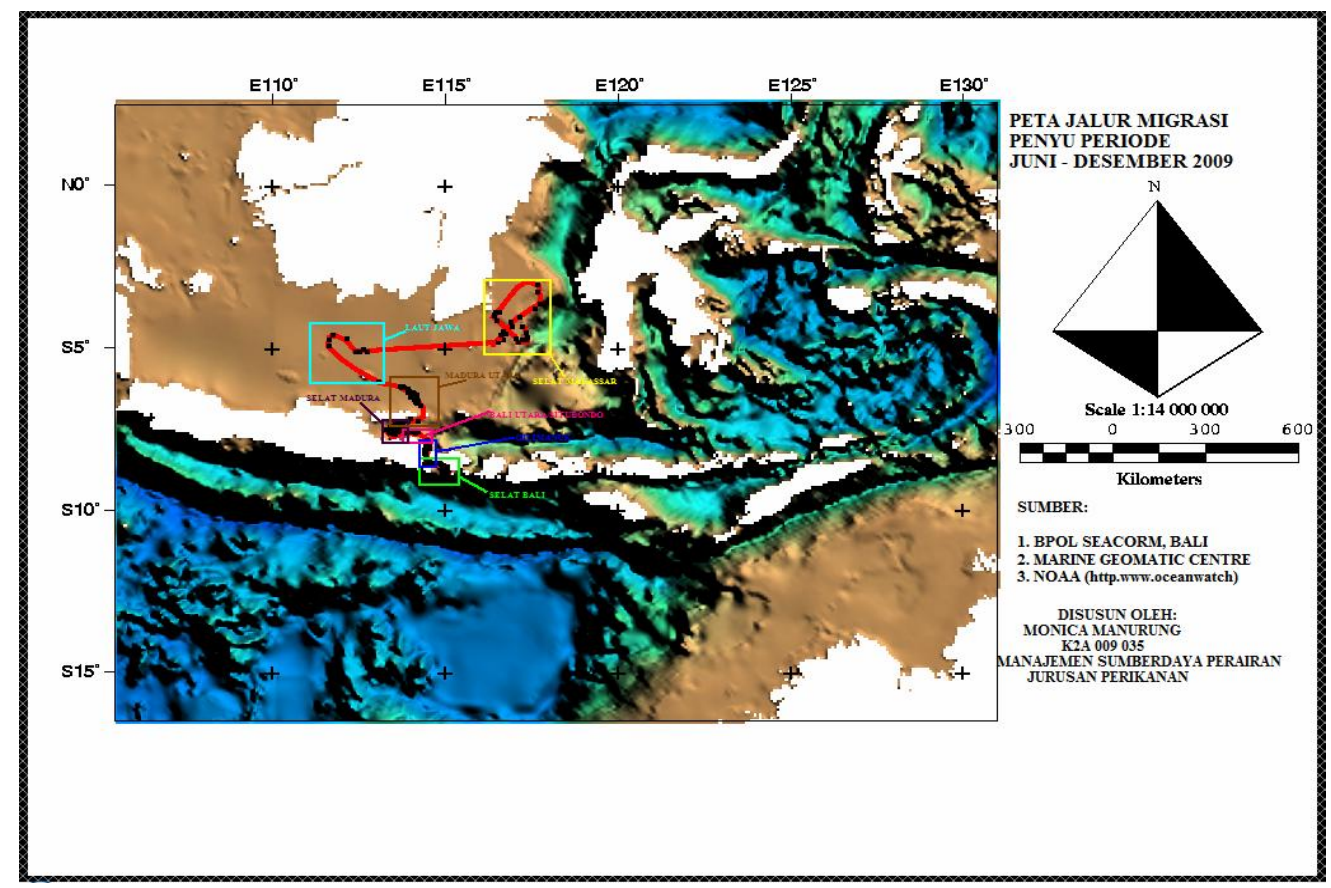

Gambar 1. Peta jalur migrasi penyu di 7 lokasi yang berbeda pada bulan

Juni, Juli, Agustus, November dan Desember 2009

Titik koordinat penyu lekang terhadap distribusi tinggi muka laut, suhu permukaan laut dan klorofil-a pada 7 lokasi yang berbeda.

1. Selat Bali (Juni)

Induk penyu yang telah dipasang transmitter berada di selat Bali sejak tanggal 1 Juni 2009 - 30 Juni 2009. Dari hasil penerimaan transmitter selama bulan Juni, didapatkan data kemunculan penyu sebanyak 81 titik lokasi (lampiran 1). Dari 81 titik lokasi kemunculan penyu, didapatkan nilai tinggi muka laut terendah $58 \mathrm{~cm}$ dan nilai tertinggi muka laut $74 \mathrm{~cm}$. Suhu permukaan laut mempunyai nilai terendah $26^{\circ} \mathrm{C}$ dan suhu tertinggi $29^{\circ} \mathrm{C}$, dan untuk nilai klorofil-a mempunyai nilai terendah $0.523 \mathrm{mg} / \mathrm{m}^{3}$ dan nilai klorofil tertinggi adalah $1.017 \mathrm{mg} / \mathrm{m}^{3}$. Hasil yang ditemukan tidak semua titik lokasi mempunyai nilai tinggi muka laut, suhu permukaan laut dan nilai klorofil-a, ini disebabkan karena tidak tersedianya data (berawan) disetiap titik lokasi penyu. Berikut adalah peta sebaran distribusi tinggi muka laut, suhu permukaan laut dan klorofil-a di selat Bali: 


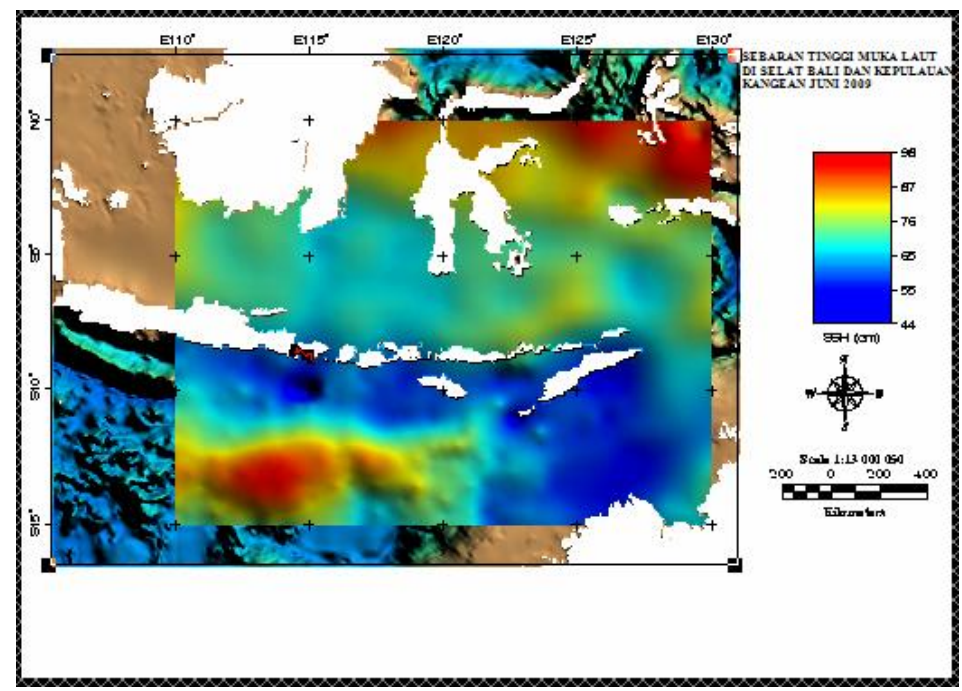

Gambar 2. Peta sebaran tinggi muka laut dan titik lokasi penyu periode 1 Juni 2009 - 30 Juni 2009

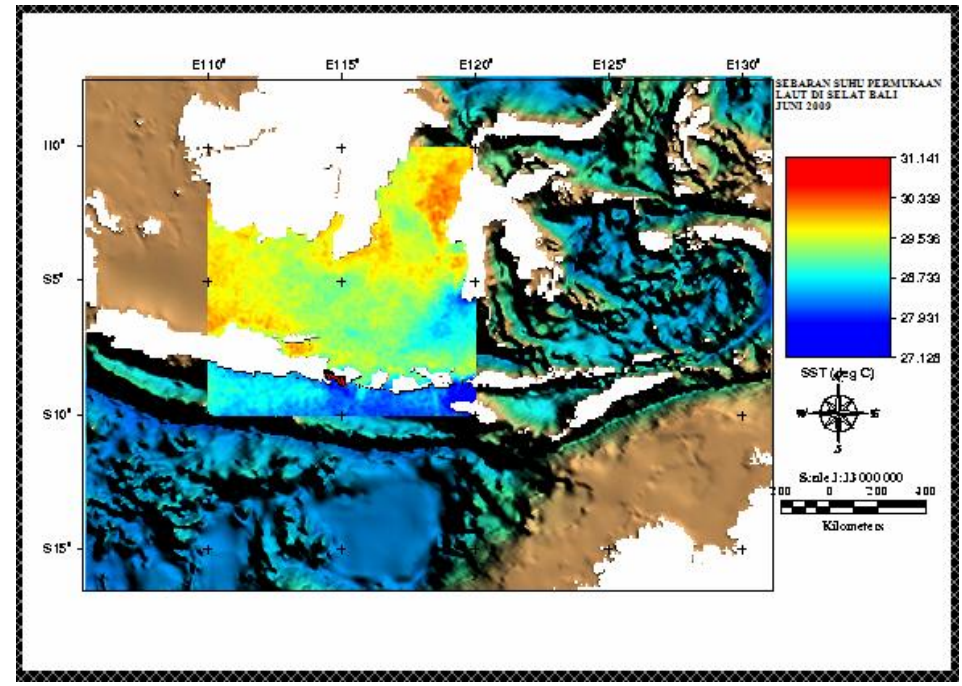

Gambar 3. Peta sebaran suhu permukaan laut dan titik lokasi penyu periode 1 Juni 2009 - 30 Juni 2009

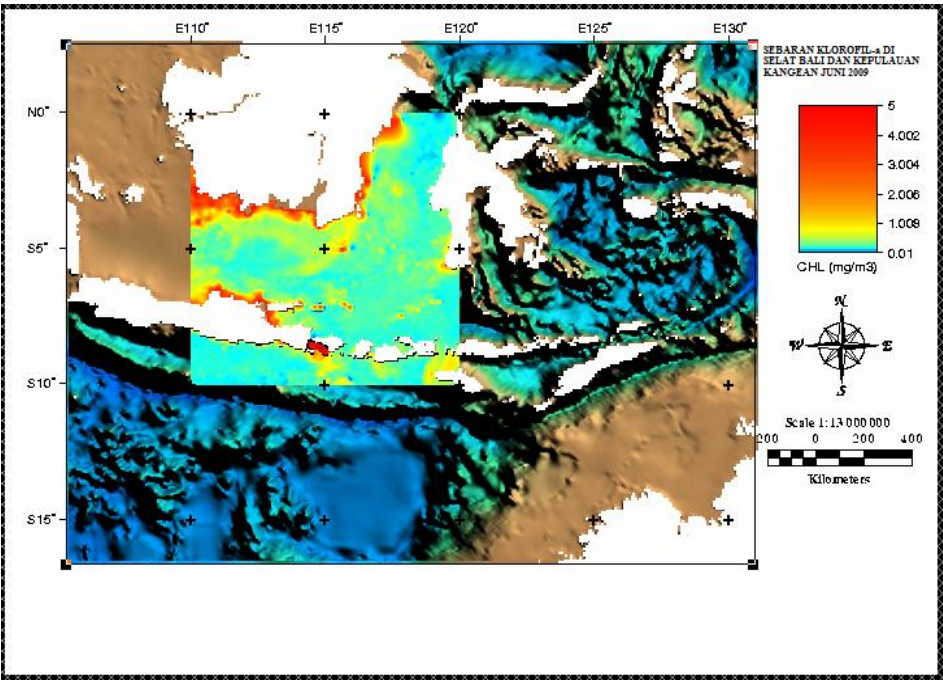

Gambar 4. Peta sebaran klorofil-a dan titik lokasi penyu periode 1 Juni 2009 - 30 Juni 2009

\section{Gilimanuk, Bali Utara dan Selat Madura (Juli)}

Induk penyu yang telah dipasang transmitter berada di Gilimanuk dan Bali Utara dan Selat Madura, dimulai sejak tanggal 1 Juli 2009 - 31 Juli 2009. Hasil penerimaan transmitter selama bulan Juli, didapatkan data kemunculan penyu sebanyak 103 titik lokasi (lampiran 1). Dari 103 titik lokasi kemunculan penyu, didapatkan nilai tinggi muka laut terendah adalah $44 \mathrm{~cm}$ dan nilai tinggi muka laut tertinggi adalah $61 \mathrm{~cm}$. Suhu permukaan laut mempunyai nilai terendah $26^{\circ} \mathrm{C}$ dan suhu tertinggi $29^{\circ} \mathrm{C}$, dan nilai klorofil mempunyai nilai terendah $0.312 \mathrm{mg} / \mathrm{m}^{3}$ 
dan nilai klorofil-a tertinggi adalah $2.77 \mathrm{mg} / \mathrm{m}^{3}$. Dari hasil yang ditemukan hanya nilai tinggi muka laut yang terdapat di semua titik lokasi, sedangkan suhu permukaan laut dan nilai klorofil-a tidak terdapat pada semua titik lokasi. Berikut adalah peta sebaran Distribusi tinggi muka laut, suhu permukaan laut dan klorofil-a di Gilimanuk, Bali Utara dan Selat Madura:

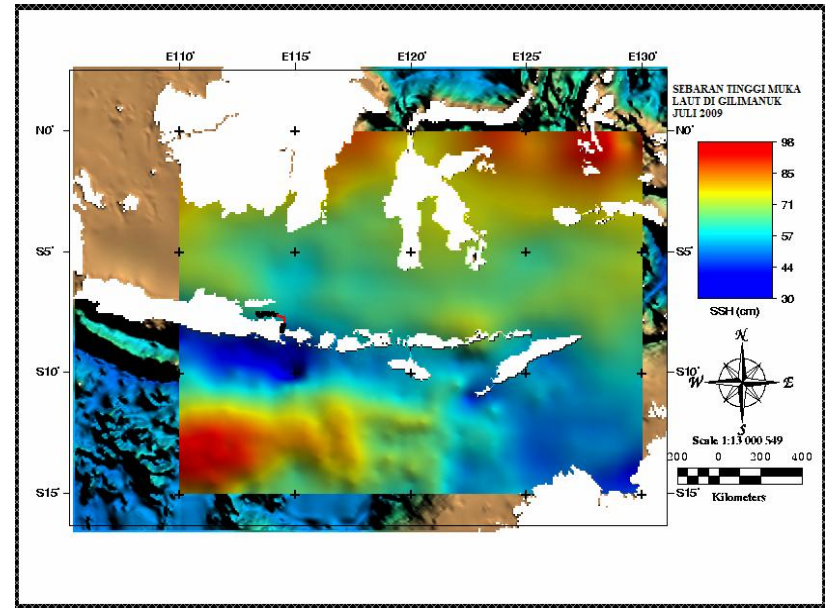

Gambar 5. Peta sebaran tinggi muka laut dan titik lokasi penyu periode 1 Juli 2009 - 31 Juli 2009

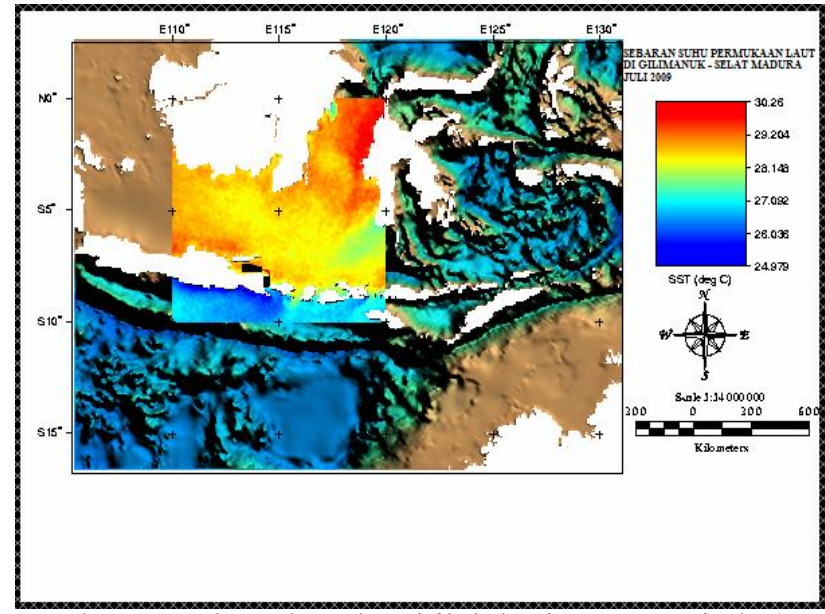

Gambar 6. Peta sebaran suhu permukaan laut dan titik lokasi penyu periode 1 Juli 2009 - 31 Juli 2009

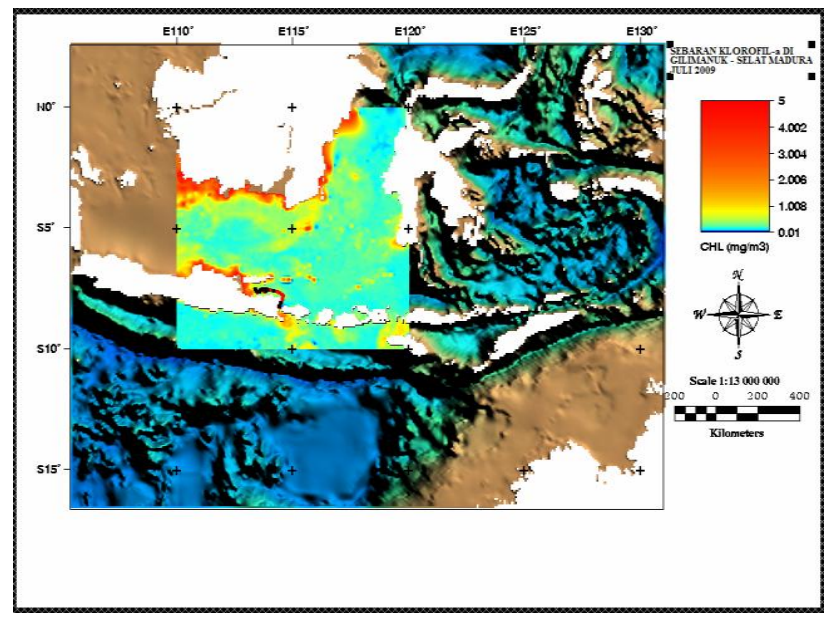

Gambar 7. Peta sebaran klorofil-a dan titik lokasi penyu periode 1 Juli 2009 - 31 Juli 2009

\section{Selat Madura-Madura Utara (Agustus)}

Induk penyu yang telah dipasang transmitter berada di Selat Madura - Madura Utara, sejak tanggal 01 Agustus 2009 - 31 Agustus 2009. Dari hasil penerimaan transmitter selama bulan Agustus, didapatkan data kemunculan penyu sebanyak 132 titik lokasi (lampiran 1). Dari 132 titik lokasi kemunculan penyu, didapatkan nilai tinggi muka laut terendah adalah $51 \mathrm{~cm}$ dan nilai tinggi muka laut tertinggi adalah $56 \mathrm{~cm}$. Suhu permukaan laut mempunyai nilai terendah $28^{\circ} \mathrm{C}$ dan suhu tertinggi $29^{\circ} \mathrm{C}$, dan nilai klorofil-a mempunyai nilai terendah $0.219 \mathrm{mg} / \mathrm{m}^{3}$ dan nilai klorofil tertinggi adalah $0.583 \mathrm{mg} / \mathrm{m}^{3}$. 
Hasil yang ditemukan tidak semua titik lokasi mempunyai nilai tinggi muka laut, suhu permukaan laut dan nilai klorofil, ini disebabkan karena tidak tersedianya data (berawan) disetiap titik lokasi. Berikut adalah peta sebaran Distribusi tinggi muka laut, suhu permukaan laut dan klorofil-a di selat Madura-Madura Utara:

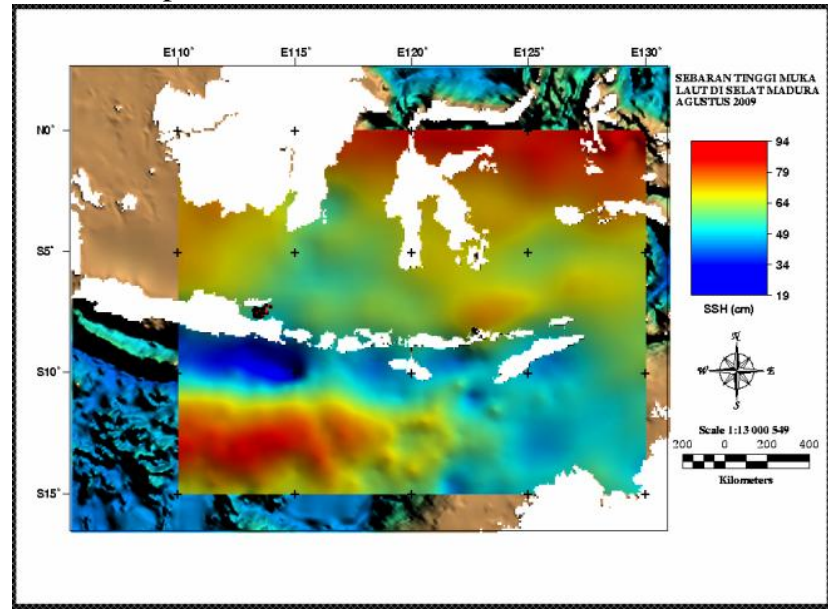

Gambar 8. Peta sebaran tinggi muka laut dan titik lokasi penyu periode 01 Agustus - 31 Agustus 2009

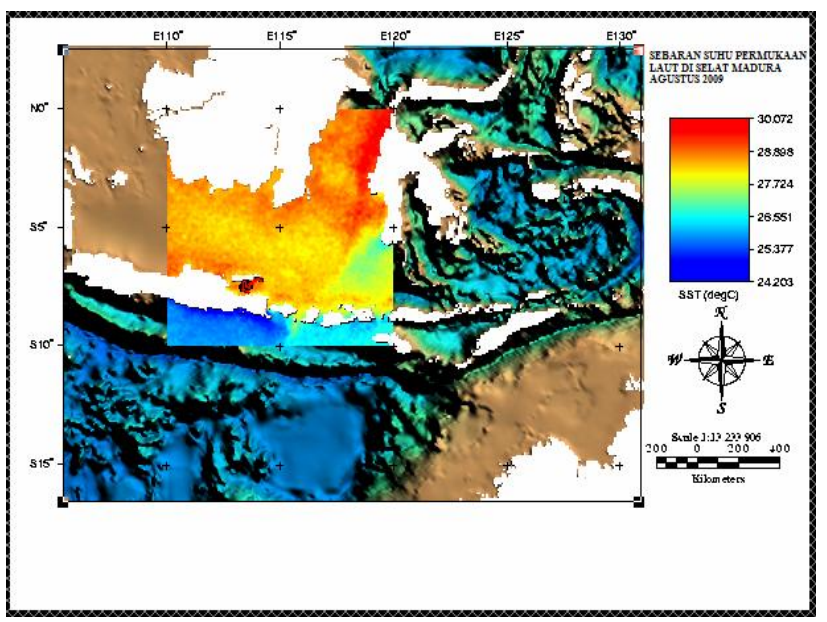

Gambar 9. Peta sebaran suhu permukaan laut dan titik lokasi penyu periode 01 Agustus - 31 Agustus 2009

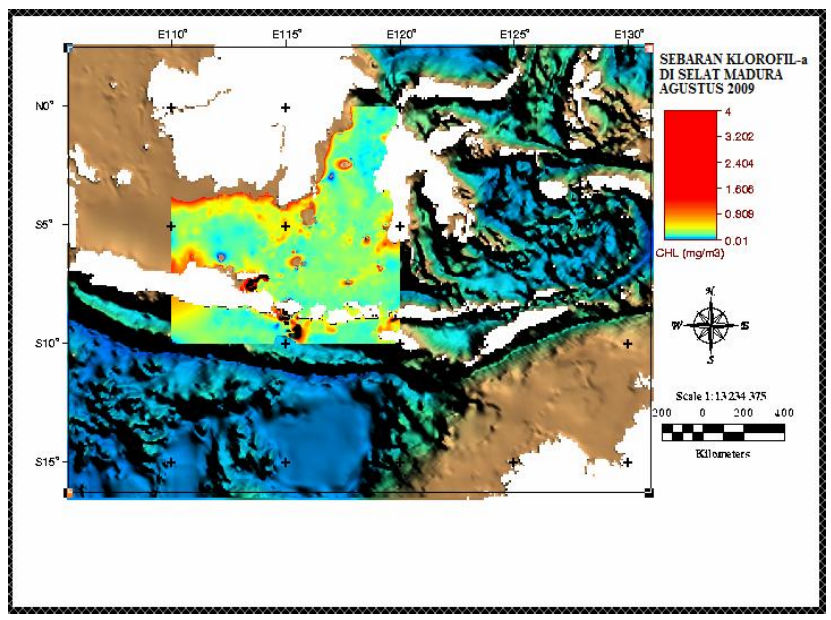

Gambar 10. Peta sebaran klorofil-a dan titik lokasi penyu periode 01 Agustus - 31 Agustus 2009

\section{Laut Jawa (November)}

Induk penyu yang telah dipasang transmitter berada di laut Jawa, sejak tanggal 03 November $2009-6$ November 2009. Dari hasil penerimaan transmitter selama bulan November, didapatkan data kemunculan penyu sebanyak 4 titik lokasi (lampiran 1). Dari 4 titik lokasi kemunculan penyu, didapatkan nilai tinggi muka laut terendah adalah $72 \mathrm{~cm}$ dan nilai tertinggi adalah $76 \mathrm{~cm}$. Suhu permukaan laut mempunyai nilai rata-rata $29^{\circ} \mathrm{C}$ dan dari hasil yang ditemukan hanya nilai tinggi muka laut dan suhu permukaan laut yang terdapat di semua titik lokasi, sedangkan nilai klorofil-a tidak terdapat pada semua titik lokasi, ini disebabkan karena tidak tersedianya data 
(berawan) di setiap titik lokasi. Berikut adalah peta sebaran distribusi tinggi muka laut, suhu permukaan laut dan klorofil-a di laut Jawa:

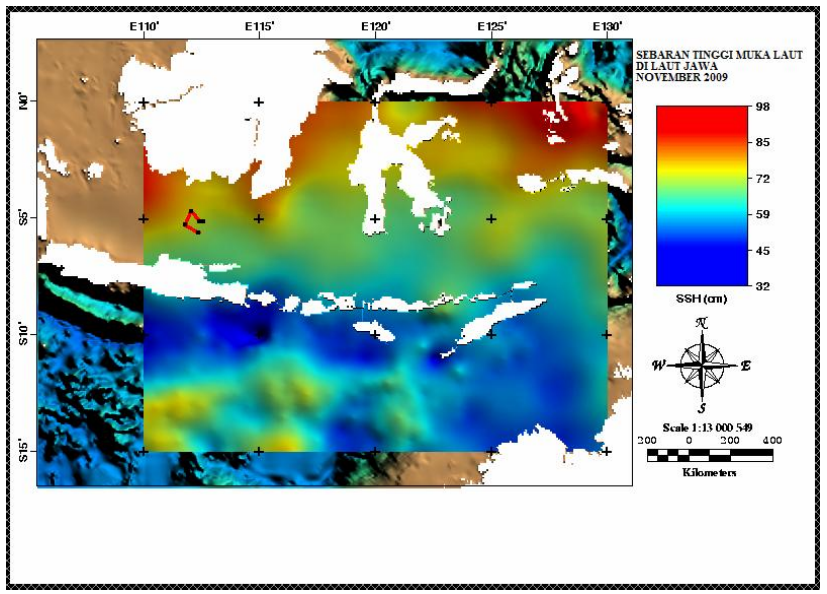

Gambar 11. Peta sebaran tinggi muka laut dan titik lokasi penyuperiode 03 November - 6 November 2009

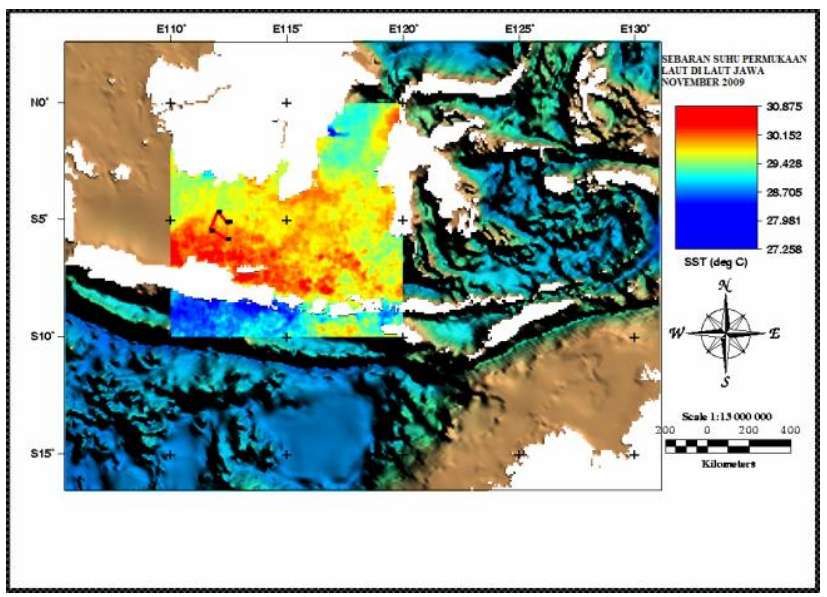

Gambar 12. Peta sebaran suhu permukaan laut dan titik lokasi penyu periode 03 November - 6 November 2009

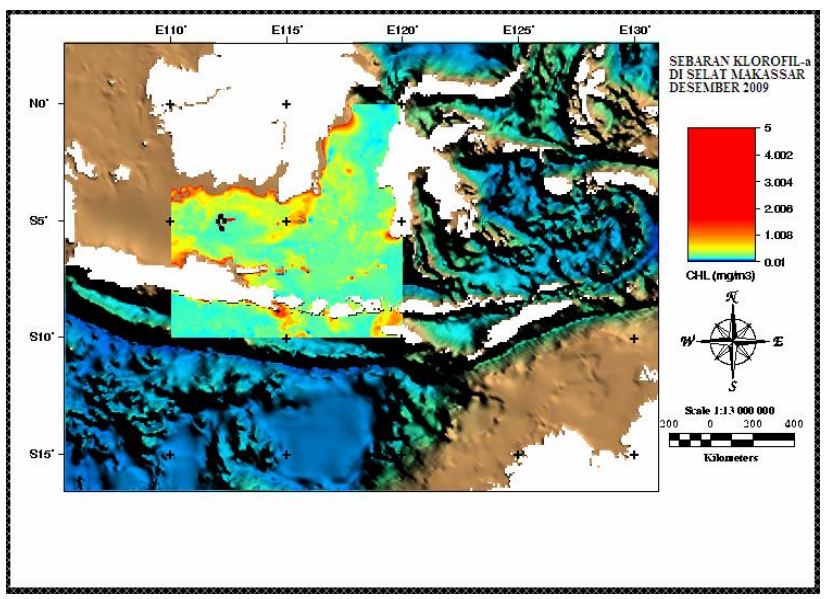

Gambar 13. Peta sebaran klorofil-a dan titik lokasi penyu periode 03November 2009 - 6 November 2009

\section{Selat Makassar (Desember)}

Induk penyu yang telah dipasang transmitter berada di Selat Makassar, sejak tanggal 9 Desember 2009 - 23 Desember 2009. Dari hasil penerimaan transmitter selama bulan Desember, didapatkan data kemunculan penyu sebanyak 23 titik lokasi (lampiran 1). Dari 23 titik lokasi kemunculan penyu, didapatkan nilai tinggi muka laut terendah adalah $77 \mathrm{~cm}$ dan tertinggi adalah $79 \mathrm{~cm}$. Suhu permukaan laut mempunyai nilai terendah $28^{\circ} \mathrm{C}$ dan suhu tertinggi $30^{\circ} \mathrm{C}$, dan untuk nilai klorofil-a nilai terendah $0.166 \mathrm{mg} / \mathrm{m}^{3}$ dan nilai klorofil-a tertinggi adalah 0.772 $\mathrm{mg} / \mathrm{m}^{3}$. Dari hasil yang ditemukan hanya nilai suhu permukaan laut yang terdapat pada semua titik sedangkan nilai tinggi muka laut dan nilai klorofil-a tidak terdapat pada semua titik lokasi, ini disebabkan karena tidak tersedianya data (berawan) disetiap titik lokasi. Berikut adalah peta sebaran distribusi tinggi muka laut, suhu permukaan laut dan klorofil-a di selat Makassar: 


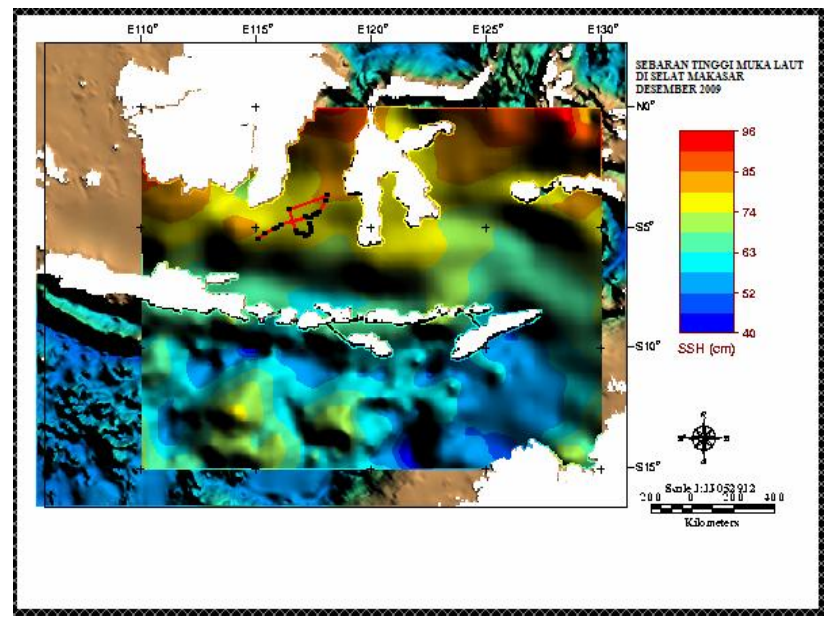

Gambar 14. Peta sebaran tinggi muka laut dan titik lokasi penyu periode 9 Desember - 23 Desember 2009

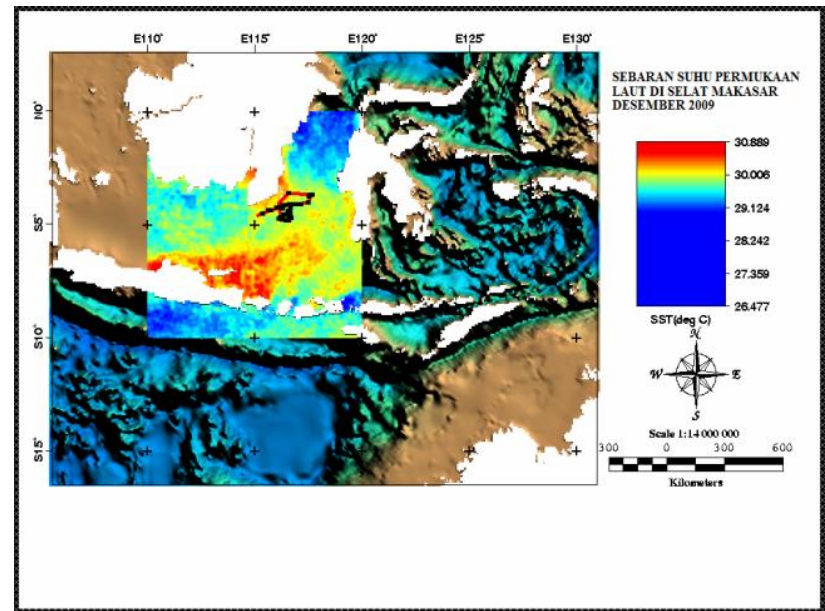

Gambar 15. Peta sebaran suhu permukaan laut dan titik lokasi penyu periode 9 Desember - 23 Desember 2009

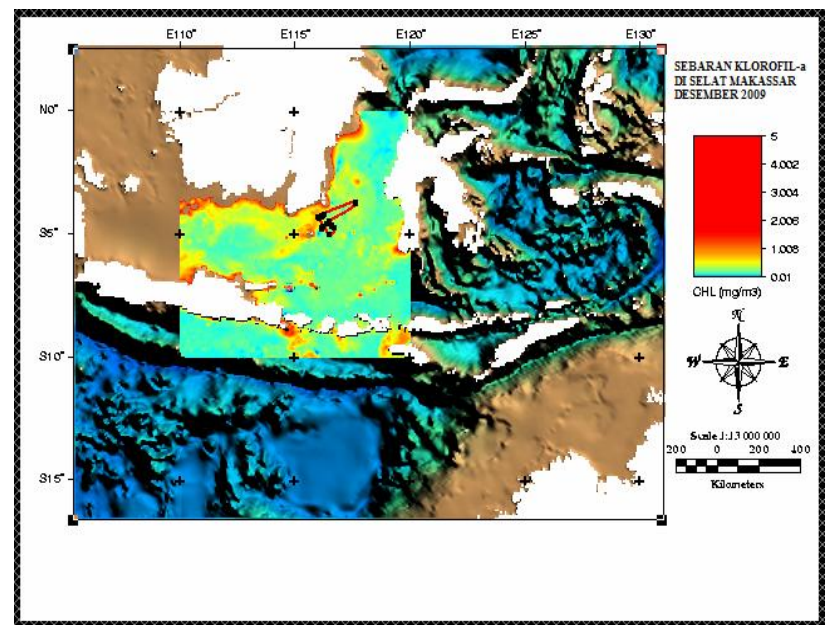

Gambar 15. Peta sebaran suhu permukaan laut dan titik lokasi penyu periode 9 Desember - 23 Desember 2009

Analisis Hubungan posisi penyu terhadap nilai tinggi muka laut, suhu permukaan laut dan klorofil-a 1. Regresi Tunggal (Single Regression)

Tabel 1. Hasil analisis korelasi regresi tunggal (Single Regression) titik koordinat penyu terhadap tinggi muka laut $(\mathrm{cm})$, suhu permukaan laut $\left({ }^{0} \mathrm{C}\right)$, dan klorofil-a $\left(\mathrm{mg} / \mathrm{m}^{3}\right)$

\begin{tabular}{lllll}
\hline \multicolumn{2}{c}{ NO. Variabel Oseanografi } & \multicolumn{1}{c}{ Persamaan Polinomial } & \multicolumn{1}{c}{$\mathbf{r}$} & \multicolumn{1}{c}{$\mathbf{R}^{\mathbf{2}}$} \\
\hline 1. & Tinggi muka laut & $\mathrm{Y}=-216+2.692 \mathrm{x}_{1}+4.503 \mathrm{x}_{2}$ & 0.873 & 0.763 \\
2. & Suhu permukaan laut & $\mathrm{Y}=50.068-0.252 \mathrm{x}_{1}+0.527 \mathrm{x}_{2}$ & 0.78 & 0.765 \\
3. & Klorofil-a & $\mathrm{Y}=-52.297+0.436 \mathrm{x}_{1}-0.433 \mathrm{x}_{2}$ & 0.694 & 0.481 \\
\hline
\end{tabular}




\section{Regresi Ganda (Multiple Regression)}

Tabel 2. Hasil analisis korelasi regresi ganda (Multiple Regression) antara titik koordinat penyu terhadap tinggi muka laut, suhu permukaan laut dan klorofil-a

\begin{tabular}{llcccc}
\hline & NO. Titik Koordinat & $\begin{array}{c}\text { Persamaan } \\
\text { Multiple Regression }\end{array}$ & $\mathbf{r}$ & $\mathbf{R}^{2}$ & Sig \\
\hline 1. & Bujur & $\mathrm{Y}=125.703-0.74_{\mathrm{X} 1}+0.46_{\mathrm{X} 2}+0.16_{\mathrm{X} 3}$ & 0.887 & 0.876 & 0.000 \\
2. & Lintang & $\mathrm{Y}=125.703-0.74_{\mathrm{X} 1}+0.46_{\mathrm{X} 2}+0.16_{\mathrm{X} 3}$ & 0.887 & 0.788 & 0.000 \\
\hline
\end{tabular}

\section{Uji Signifikan Regresi}

a. Regresi Tunggal (Single Regression)

Tabel 3. Hasil uji signifikan regresi tunggal antara titik kordinat penyu terhadap tinggi muka laut, suhu permukaan laut dan klorofil-a

\begin{tabular}{cccc}
\hline No. & Variabel & Nilai Sig & nilai $\boldsymbol{\sigma}$ \\
\hline 1. & Tinggi Muka Laut & 0 & 0.05 \\
& & 0 & 0.05 \\
\hline 2. & Suhu Permukaan Laut & 0 & 0.05 \\
& & 0 & 0.05 \\
\hline 3. & Klorofil-a & 0 & 0.05 \\
& & 0 & 0.05 \\
\hline
\end{tabular}

b. Regresi Ganda (Multiple Regression)

Tabel 4. Hasil uji signifikan regresi Ganda antara titik kordinat penyu terhadap tinggi muka laut, suhu permukaan laut dan klorofil-a

\begin{tabular}{clcc}
\hline No. & \multicolumn{1}{c}{ Variabel } & Nilai Sig & Nilai $\boldsymbol{\sigma}$ \\
\hline 1. & $\begin{array}{l}\text { Tinggi Muka Laut, Suhu Permukaan Laut, } \\
\text { dan Klorofil-a }\end{array}$ & 0 & 0.05 \\
\hline
\end{tabular}

Keterangan: $\operatorname{sig}<\sigma=$ berpengaruh; sig $>\sigma=$ tidak berpengaruh

Berdasarkan data lokasi penyu lekang yang telah dipasang transmitter. Penyu telah melakukan migrasi pada tujuh lokasi berbeda dan terpantau satelit berawal dari pelepasan di pantai Perancak, Jembrana-Bali hingga terakhir terpantau di Selat Makassar. Pada penelitian ini, data yang diterima oleh satelit yaitu selama lima bulan, diawali Juni, Juli, Agustus, November dan berakhir bulan Desember tahun 2009. Pergerakan penyu lekang yang terpasang transmitter yaitu berawal dari pantai Perancak, penyu berenang disekitar selat bali (Juni 2009) menuju Gilimanuk (01 - 12 Juli 2009) melakukan ruaya kembali ke Bali Utara/Situbondo (13 - 16 Juli 2009) kemudian menuju Selat Madura (17 Juli - 30 Agustus 2009) diteruskan menuju Madura Utara (31 Agustus), dilanjutkan kembali menuju Laut Jawa (3 November - 06 November 2009) dan terakhir berada di Selat Makassar (09 Desember 2009 - 23 desember 2009). Dari hasil yang didapatkan menunjukkan bahwa pada penelitian ini selama bulan desember di selat Makassar yang merupakan daerah terakhir dari migrasi penyu maka berdasarkan pola arus pada musim barat (Desember) penyu lekang diprediksikan akan bermigrasi menuju kalimantan Timur. Menurut Dahuri 2003, persebaran penyu lekang di Indonesia berada di Sumatera, Alas Purwo-Jawa Timur, Paloh-Kalimatan Timur dan Nusa Tenggara Timur (NTT).

Pada musim timur (Juni, Juli dan Agustus, November 2009), penyu lekang yang terpasang transmitter berada di perairan Selat Bali, Bali Utara dan Selat Madura, sedangkan saat musim barat (bulan Desember 2009) penyu lekang berada di perairan Selat Makassar (09 Desember 2009). Dengan mengetahui lokasi jelajah penyu maka dapat membantu dalam menentukan Kawasan Konservasi Laut (KKL), dengan mengetahui lokasi pergerakan penyu dapat dibuat suatu kebijakan untuk pelestarian spesies penyu tersebut. Tempat-tempat yang menjadi wilayah jelajah penyu dapat direkomendasikan sebagai salah satu dasar dalam pembentukan koridor atau jaringan Kawasan Konservasi Laut (KKL), Turtle tagging adalah salah satu upaya melakukan observasi laut secara kontinyu, berdaya-jangkau luas dan berwawasan lingkungan (BROK, 2009).

Nilai tinggi muka laut, suhu permukaan laut dan klorofil-a yang telah dilakukan analisis regresi korelasi antara titik kemunculan penyu lekang yang telah dipasang transmitter terhadap nilai tinggi muka laut, suhu permukaan laut dan klorofil-a. Pada penelitian ini didapatkan nilai tinggi muka laut, suhu permukaan laut dan klorofil-a yang beragam disetiap lokasi kemunculan penyu pada bulan Juni 2009 hingga Desember 2009. Tinggi muka laut didapatkan data sebanyak 269, suhu permukaan laut sebanyak 310 data dan untuk data klorofil-a sebanyak 195 yang sesuai dengan titik koordinat penyu. Data yang didapatkan menyatakan bahwa tinggi muka laut mempunyai nilai yang lebih tinggi dibandingkan suhu permukaan laut dan klorofil-a, hal ini disebabkan banyaknya data nilai klorofil-a yang tertutup awan dan nilai ini mengindikasikan bahwa korelasi klorofil terhadap migrasi penyu lebih kecil daripada tinggi muka laut dan suhu permukaan laut. Menurut Kushartono (2009), pada masa perkembangbiakannya, penyu harus berpindah dari daerah tempat mencari makannya ke pantai tempat bertelurnya, dan untuk beberapa spesies perpindahan migrasi ini dilakukan dengan menempuh jarak yang jauh.

Data penelitian ini pada musim timur berlangsung pada bulan Juni sampai November 2009. Selama musim ini nilai minimum tinggi muka laut (TML) didapatkan $44 \mathrm{~cm}$ dan nilai maksimum tinggi muka laut (TML) didapatkan 
$76 \mathrm{~cm}$, namun tidak semua titik koordinat mempunyai nilai tinggi muka laut karena data tidak sesuai dengan titik koordinat penyu. Nilai minimum suhu permukaan laut dari bulan Juni hingga Agustus yaitu $26^{\circ} \mathrm{C}$ dan nilai maksimumnya yaitu $29^{\circ} \mathrm{C}$. Penyu lekang biasanya hidup pada garis isotherm $20^{\circ} \mathrm{C}$, di luar suhu perairan ini pernah di temukan tetapi dengan catatan suhu air tidak kurang dari $15^{\circ} \mathrm{C}$ yaitu $20^{\circ} \mathrm{C}-30^{\circ} \mathrm{C}$ (Nybakken dan James, 1998).

Nilai minimum klorofil-a yang didapatkan adalah $0,219 \mathrm{mg} / \mathrm{m}^{3}$ dan nilai maksimum klorofil-a yang didapatkan adalah $2.77 \mathrm{mg} / \mathrm{m}^{3}$, Pada musim timur nilai klorofil lebih tinggi dibandingkan musim barat, ini dikarenakan bahwa posisi matahari berada di Utara garis khatulistiwa sehingga pada bulan Juni sampai November yang merupakan musim kemarau di Indonesia akan meningkatkan nilai klorofil-a di musim timur dimana dengan bantuan sinar matahari maka pigmen klorofil-a akan melakukan proses fotosintesis dan menghasilkan nilai klorofil-a yang tinggi di perairan tersebut. Sehubungan dengan klorofil-a, penyu laut biasanya hidup tetap dalam kisaran 0,05 - 7,63 $\mathrm{mg} / \mathrm{m}^{3}$ (Parson et al., 1984 dalam Realino et al., 2005).

Musim barat terjadi pada bulan Desember hingga Februari. Pada musim barat dalam penelitian ini hanya menggunakan data bulan Desember 2009, sebab data bulan Januari dan Februari 2010 tidak diperoleh data yang signifikan, ini dikarenakan penyu yang telah dipasang oleh transmitter sudah tidak terpantau lagi.

Pada bulan Desember 2009, nilai minimum untuk tinggi muka laut $77.091 \mathrm{~cm}$ dan nilai maksimum adalah $79.466 \mathrm{~cm}$. Nilai tinggi muka laut pada musim barat mempunyai nilai yang lebih tinggi dibandingkan musim timur yang hanya $44 \mathrm{~cm}-76 \mathrm{~cm}$, ini diakibatkan karena posisi matahari berada di selatan Indonesia atau di bawah garis khatulistiwa, sehingga pada musim barat (musim hujan), pola arus di perairan Indonesia yang diakibatkan oleh tekanan, angin, densitas yang mengalir dari Utara Indonesia menuju ke Selatan Indonesia sehingga mengakibatkan perbedaan tinggi muka laut di Perairan Selat Makasar (Desember). Adanya pengaruh arus lintas di perairan selat Makasar yang disebut Arlindo maka daerah ini merupakan daerah yang kaya akan nutrien dan unsur-unsur hara dan sebagai tempat berkumpulnya ikan pelagis seperti ikan layang (sardinella Sp) yang merupakan makanan penyu lekang. Nilai minimum untuk suhu permukaan laut $29^{\circ} \mathrm{C}$ dan nilai maksimum adalah $30^{\circ} \mathrm{C}$. Penyu adalah hewan jenis reptil yang termasuk poikilotherm (suhu tubuh mengikuti suhu lingkungan) sehingga mampu menyelam dalam waktu yang lama dan merupakan golongan ectothermic (berdarah dingin). Beberapa spesies ikan umumnya hidup, mencari makan, memijah dan melakukan aktivitas lainnya pada suhu yang sesuai dengan lingkungannya sehingga suhu di dalam perairan merupakan salah satu faktor yang sangat penting dalam mengatur proses kehidupan dan penyebaran organisme, khususnya penyu (Nybakken dan James, 1998).

Nilai minimum klorofil-a terhadap titik koordinat penyu adalah $0.166 \mathrm{mg} / \mathrm{m}^{3}$ dan nilai maksimum adalah $0.772 \mathrm{mg} / \mathrm{m}^{3}$. Klorofil-a merupakan pigmen yang paling umum terdapat pada fitoplankton sehingga kelimpahan fitoplankton dapat dilakukan melalui pengukuran konsentrasi klorofil-a di perairan. Klorofil-a merupakan pigmen hijau plankton yang digunakan dalam proses fotosintesis, semua fitoplankton mengandung klorofil-a yang beratnya kira-kira 1 - 2\% dari berat kering alga dan penyu laut biasanya hidup tetap dalam kisaran $0,05-7,63 \mathrm{mg} / \mathrm{m}^{3}$. (Parson et al., 1984 dalam Realino et al., 2005).

Hasil penelitian ini dilakukan dengan analisa regresi tunggal (Single Regression) dan analisa regresi ganda (Multiple Regression). Analisa regresi tunggal (Single Regression) menganalisa pengaruh titik koordinat tracking penyu terhadap masing-masing variabel (tinggi muka laut, suhu permukaan laut, dan klorofil-a). Analisa regresi ganda (Multiple Regression) menganalisa pengaruh titik koordinat tracking penyu terhadap penggabungan semua variabel sekaligus dengan jumlah nilai data tinggi muka laut, suhu permukaan laut, dan klorofil-a yang sama, yang diambil dari data 5 (lima) bulan yaitu Juni, Juli, Agustus, November dan Desember 2009.

Pada analisis regresi tunggal (Single Regression), nilai koefisien kolerasi (r), diduga posisi titik koordinat penyu memiliki hubungan yang lebih erat dengan nilai (r) Tinggi Muka Laut (TML) yaitu 0.873, ini mengindikasikan bahwa nilai (r) 0.873 mempunyai arti interpretasi atau hubungan yang tinggi. Hal ini dinyatakan Hadi (2004) dalam klasifikasi nilai koefisien korelasi bahwa 0.8 - 1 mempunyai interpretasi/korelasi yang tinggi. Nilai (r) suhu permukaan laut yaitu 0.78 yang menunjukkan bahwa nilai ini memiliki interpretasi sedang, dan untuk klorofil-a didapatkan nilai (r) yaitu 0.69 menunjukkan bahwa interpretasi/hubungan yang sedang. Berdasarkan uji regresi menggunakan SPSS didapatkan nilai koefisien korelasi (r) dan nilai koefisien determinasi ( $R$ square). Koefisien korelasi digunakan untuk menunjukkan kekuatan dan kelemahan dari suatu hubungan, sedangkan koefisien determinasi adalah suatu nilai yang menggambarkan seberapa besar perubahan dari variable dependen bisa dijelaskan oleh perubahan atau variasi dari variable independen (Hamidi, 2007).

Pada analisis regresi ganda (Multiple Regression), nilai koefisien korelasi (r), diduga posisi penyu memiliki hubungan yang erat dengan ketiga variabel oseanografi, dengan nilai (r) pada titik koordinat Bujur yaitu 0.936 dan titik koordinat Lintang yaitu 0.887. Hal ini menunjukkan bahwa nilai (r) yaitu 0.936 dan 0.887 mempunyai interpretasi atau hubungan yang tinggi antara posisi penyu dan seluruh variabel oseanografi yang diteliti. Hal ini dinyatakan Hadi (2004) dalam klasifikasi nilai koefisien korelasi bahwa 0.8 - 1 mempunyai interpretasi/korelasi yang tinggi.

Uji signifikan regresi pada regresi tunggal (Single Regression), nilai signifikan pada tinggi muka laut yaitu 0 dan nilai $\sigma 0.05$ dan apabila nilai sig $<\sigma$, maka ini menunjukkan adanya pengaruh antara tracking penyu dengan tinggi muka laut, sama halnya dengan nilai signifikan pada suhu permukaan laut yaitu 0 dan nilai $\sigma 0.05$ dan apabila nilai sig < $\sigma$, maka ini menunjukkan bahwa adanya pengaruh antara tracking penyu dengan suhu permukaan laut. Nilai signifikan pada klorofil-a yaitu 0 dan nilai $\sigma$ yaitu 0.05 . Apabila nilai sig $<\sigma$, maka ini menunjukkan adanya pengaruh antara tracking penyu dengan klorofil-a. 
Untuk uji signifikan regresi ganda (Multiple Regression), nilai signifikan pada tinggi muka laut, suhu permukaan laut dan klorofil-a pada posisi numerik bujur dan lintang adalah 0 dan nilai $\sigma$ yaitu 0.05 dan apabila nilai sig $<\sigma$, maka ini menunjukkan adanya pengaruh antara tracking penyu dengan semua variabel (tinggi muka laut, suhu permukaan laut, dan klorofil-a).

\section{Kesimpulan}

Kesimpulan yang didapatkan dari penelitian ini adalah:

1. Penyu Lekang (Lepidochelys olivacea) yang telah di pasang transmitter terpantau jalur migrasinya berawal dari Selat Bali, Gilimanuk, Bali Utara/Situbondo, Selat Madura, Madura Utara dan berakhir di Selat Makassar;

2. Distribusi Tinggi Muka Laut (TML) berdasarkan titik koordinat penyu selama lima bulan (Juni, Juli, Agustus, November dan Desember) pada tujuh lokasi yang berbeda yaitu dengan nilai minimum $44 \mathrm{~cm}$ dan maksimum $79 \mathrm{~cm}$, sedangkan distribusi Suhu Permukan Laut (SPL) yaitu dengan nilai minimum $26{ }^{0} \mathrm{C}$ dan maksimum 30 ${ }^{0} \mathrm{C}$, dan untuk distribusi Klorofil-a berdasarkan titik koordinat penyu, dengan nilai minimum $0.219 \mathrm{mg} / \mathrm{m}^{3} \mathrm{dan}$ maksimum $2.77 \mathrm{mg} / \mathrm{m}^{3}$; dan

3. Korelasi/keeratan hubungan posisi penyu terhadap Tinggi Muka Laut (TML), dengan nilai (r) yaitu 0.873 mempunyai interpretasi yang tinggi. Nilai (r) Suhu Permukaan Laut (SPL) yaitu 0.78 dan nilai (r) klorofil-a yaitu 0.69, nilai ini menunjukkan bahwa Suhu Permukaan Laut (SPL) dan Klorofil-a mempunyai interpretasi sedang.

\section{Daftar Pustaka}

BROK (Balai Riset Observasi Kelautan), 2009. Turtle Tagging Kerjasama BROK/BRKP-CLS/Perancis-Kurma Asih di Bali.

Dirjen Perikanan, 1993, Petunjuk pelaksanaan dan Pembinaan dan Pengelolaan Penyu Laut di Indonesia, Direktoral Jenderal Perikanan, Direktoral Bina Sumber Hayati, Jakarta.

Hadi, S. 2004. Metodologi Research. Andi, Yogyakarta, 300 - 303 hlm.

Hartoko, A. 2013. Aplications of Sea Surface Height Data For Oceanography and Marine Resources Studies of the Pacific, Indonesia and Indian Ocean.

Diponegoro University, Semarang, $46 \mathrm{hlm}$

Kushartono, Edi Wibowo. 2009. Identifikasi Penyu. Universitas Diponegoro, Semarang. 72 hlm.

Nybakken, dan W. James. 1998. Biologi, Suatu Pendekatan Ekologi (Terjemahan: Moh. Eidman dan Kuesoebiono). PT. Gramedia. Jakarta. Hal. 138 - 140.

Realino, B. 2005. Peningkatan Informasi Daerah Penangkapan Ikan Melalui Integrasi Teknologi Inderaja Permodelan Hidrodinamika dan Bioakustik. Badan Riset Kelautan dan Perikanan. Departemen Kelautan dan Perikanan. Jakarta

Samedi, 2000. "Masalah Penyu Hijau di Bali: Gambaran Kompetisi Kehidupan yang Tidak Seimbang". Majalah Kehutanan Indonesia. Edisi 3/XIV/2000. 